\title{
Understanding Dizziness: Overview of Balance System in Human
}

\author{
Mi Ran Bae \\ Department of Otorhinolaryngology-Head \& Neck Surgery, Balance Clinic, Yonsei University College of Medicine, Seoul, Korea
}

\section{어지럼증의 이해: 평형장애 평가 및 재활}

배 미 란

연세대학교 의과대학 이비인후과학교실 Balance Clinic

\begin{abstract}
Cancelation of the external force by applying equal amount of reaction to prevent from tilting to a side is called balance. Since of balance is an ability to maintain balance of human when one's center of gravity (COG) shifts by a certain change in posture. When the receptor fails to receive information appropriately, dizziness occurs and maintaining the posture become challenging. Balance disorder can be determined by series of examinations that analyzes general site and the degree of disability through Vestibulao-ocular reflex (VOR). Implementing comprehensive and systematic customized rehabilitation program based on the type of balance disorder not only help patients to recover effectively but also help them to return to their daily life in a short time.
\end{abstract}

Key Words: Balance, COG, Dizziness, VOR, Rehabilitation.

Received: March 2, 2016 / Accepted: March 10, 2016

Correspondence: Mi Ran Bae, Department of Otorhinolaryngology-Head \& Neck Surgery, Balance Clinic, Yonsei University College of Medicine, 50-1 Yonsei-ro, Seodaemun-gu, Seoul 03722, Korea

Tel: +82-2-2228-1288 / Fax: +82-2-2228-3490 / E-mail: bae@yuhs.ac

\section{INTRODUCTION}

인체는 주위 환경의 자극을 받아들일 때, 특히 공간에서 개 체가 평형을 이루게 하기 위해 시각계(visual system), 전정계 (vestibular system) 그리고 체감수용계(proprioceptive system)라는 감각기를 활용한다. 각 감각기는 전달 받은 정보를 활용하여 복합적인 신체활동으로 표현한다. 시각계는 전방의 물체를 주시하여 그 위치를 파악함과 동시에 안정된 시야를 확 보할 수 있도록 하고 전정계는 측두골의 추체부에 위치하면서 시각계, 체감수용계 등과 함께 반사적인 자세나 운동의 조절뿐 만 아니라 자극에 대한 자율신경계 기능의 조절에 중요한 역할 을 한다. 1907년 Barany에 의하여 전정반사(vestibular reflex) 에 관한 연구가 시작된 이래로 전정계의 해부학적 구조 및 생리 적인 기능에 관한 연구가 활발하게 이루어졌다. 1950년대에 Szentagothai가 전정안반사로(vestibulo-ocular reflex arc)모 델을 제시하였으며 이어 Peterson et al.(1985)은 전정척수반사 (vestibulo-spinal reflex, VSR), 경부목반사(cervico-colic re- flex, CCR)와 전정목반사(vestibulo-collic reflex, $\mathrm{VCR}$ )등이 균형을 유지시키기 위한 신체 움직임에 효과적으로 작동한다 고 설명하였다.

인체는 전정계로 들어온 정보를 시각과 척수반사로를 통해 수집된 자료들과 함께 전정핵(vestibular neucleus)을 중심으로 중추신경계에 집중시킨다. 여기에서 종합되어 분석된 정보는 전정안반사(vestibule occular reflex)라는 반사궁을 통해 안정 된 시야를 유지하고, 전정척수반사를 통해 운동신경을 활성화 시켜 신체가 한 방향으로 치우침 없이 일정한 자세를 유지하는 것이 가능하게 한다. 안정된 시야확보가 가능하도록 머리의 위 치를 일정하게 유지하게 하는 전정 목반사 및 경부반사도 일어 나며 결과적으로 인체는 평형을 유지하려는 목적을 달성하게 된다(Lee et al., 2005).

전정계의 이상은 어지럼이나 신체의 균형을 유지하기 어려운 증상 즉, 평형장애로 나타난다. 이러한 평형장애는 Figure 1의 표로 설명할 수 있는데 내이 전정계, 시각계, 체감수용계의 심 부지각기(proprioceptive system)와 기타의 감각기로부터 오는 


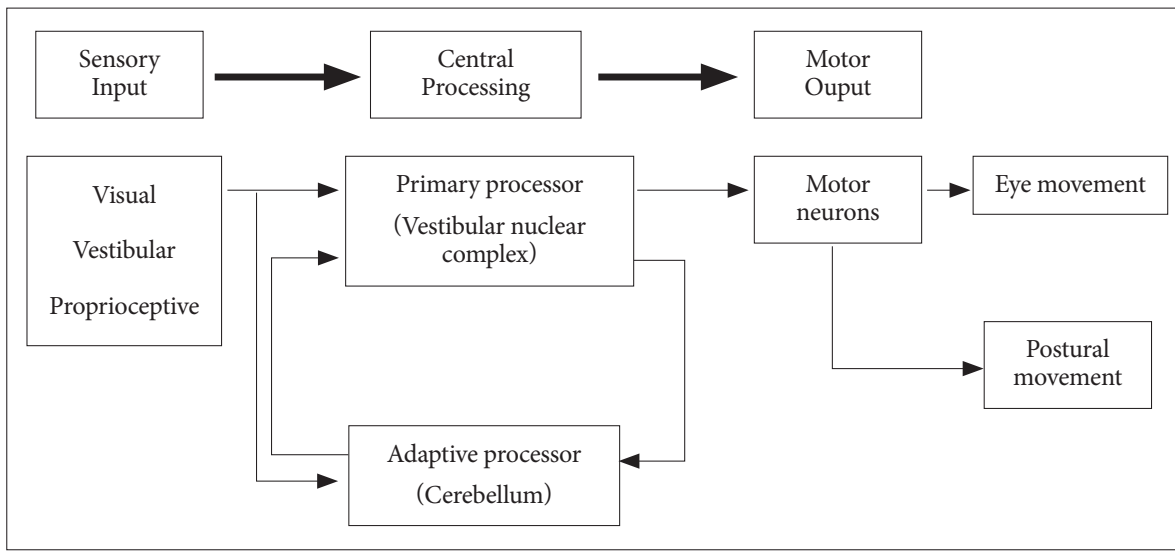

Figure 1. The organization of the vestibular system.
구심성 정보가 뇌중추에서 원활히 통합되고, 여기서 나오는 원 심성 신경이 안구운동(oculomotor system), 사지운동(spinal motor system)에 관계하는 근 긴장의 변화를 반사적으로 조절 하는 양쪽의 평형 반사회로(reflex arc)의 혼란으로 일어난다. 이렇게 신체의 평형을 유지하는 데에는 내이 전정뿐만 아니라 시각, 심부지각기 및 뇌간, 소뇌 등 뇌중추가 관여하고 있음을 설명하고 있다(Herdman et al., 2007). 즉 어지러움과 평형장애 를 일으키는 질환은 말초전정 질환, 중추전정 질환, 심장질환, 전신질환, 안과질환, 원인 불명의 어지럼 등 수 없이 많다. 어지 러움이나 평형장애를 호소하는 질환을 진단하려면 문진, 전정 기능 검사, 신경학적검사, 전신검사, 이과적 검사와 전산화단층 촬영(Computerized Tomography, CT), 자기공명영상(Magnetic resonance imaging, MRI) 등의 방사선 검사 등 체계적이 고 유기적인 평가와 이해가 필요하다(Rhee, 2003).

\section{PERCEPTION OF HUMAN BALANCE SYSTEM}

어지럼은 지구상에 존재하며 생활을 영위하는 개체가 정적 인 중력의 힘을 인지하는 작용이 변형되는 상태로서, 개체나 환경이 회전하는 감각을 느끼게 되는 증상으로 나타나며 이것 은 개체의 생리적인 반응의 결과이거나 혹은 감수기의 병적인 상태를 대변하게 된다. Baloh(1996)는 어지럼증이란 공간과 관 계된 감각으로 특별하게 표현하기 어려운 증상이라고 설명한 다. 왜냐하면 그것은 매우 주관적이고 정량화하기가 어려우며 여러 가지 질병과 병리적인 현상에 의해 중복되어 나타날 수도 있기 때문이다.

개체가 위치한 곳에서 일어나는 현상들은 공간 인지계에 의 해서 감지된다. 이때 시각계, 전정계와 체감수용계가 주로 외부 로부터의 자극을 수용하는 감수기로 작용한다. 각 감수기로부 터 입력되는 모든 정보들은 인체 평형계에서 종합되고 결과적
으로는 안구와 머리 운동 그리고 환경에 대한 신체의 인지 및 운동반사, 주위 환경의 움직임에 대한 인지로 이해되는 지각 반 응으로 표출된다. 전정계는 머리의 직선 및 곡선, 가속 및 감속 운동으로 인한 정보를 중추신경계에 전달하고 안구의 근육운 동에 의한 시야의 안정성에 도움을 주며 자세유지를 위한 근육 의 긴장도를 조절하는 기능을 가진다. 따라서 평형계에서 표출 되는 현상은 비정상적인 정보 입수, 감각기의 병리 상태 및 중 추 신경전달경로의 이상 상태 등이 반영된 총체적인 결과라고 할 수 있다.

전정계는 말초전정계와, 중추전정계 및 효과기로 구분할 수 있으며 말초전정계는 머리의 움직임에 대한 정보를 감지하여 전정신경핵과 소뇌에 있는 중추신경계에 전달하여 주는 역할 을 하고, 중추 신경계는 말초신경계로부터 오는 정보를 시각 및 체감수용계 같은 다른 감각기에서 온 정보와 통합하여 머리의 위치 및 움직임을 확인하고 이를 조율하여 하부기관에 명령을 내리는 역할을 한다. 효과기는 중추신경계의 조절 하에 전정안 반사와 전정척수반사를 통하여 안구근육이나 척추주변의 근 육이 신체의 균형을 유지하도록 작용시키는 역할을 한다.

전정기관은 이러한 평형계의 인지활동에 정보를 제공 한다. 전정계는 머리의 직선 및 곡선, 가속 및 감속운동으로 인한 정 보를 중추신경계에 전달하고 안구의 근육운동에 의한 시야의 안정성에 도움을 주며 자세유지를 위한 근육의 긴장도를 조절 하는 기능을 가진다. 전정기관에 자극을 유발하는 요소는 관 성의 힘이라고 할 수 있다. 이 힘은 가속 효과나 중력으로 인하 여 합동 된 어떤 힘에 의해서 전정기관 감수기의 특정 부분에 질량으로 가해지는 효과 때문에 유발되는 힘이다. 전정감수기 의 자극 수용은 기본적으로 중추기관으로의 정보 전달 기능을 가지는 것으로서 그 정보는 대부분 주변 환경에서의 머리의 자 세와 움직임에 대한 인지를 통해 이루어진다. 또 시각계의 인지 기능은, 시야가 정지되어 있고 안정된 정상적인 환경에서는 전 정계와 동일한 기능을 가지게 되며 시각 정보를 중추기관으로 
전달한다. 하지만 시각계는 움직이는 환경에 놓이게 되면 개체 의 운동에 대해 왜곡된 정보를 전달하게 되고 중추평형계는 일 정하게 안정상태 유지를 가능하게 하는 정보를 요구하게 된다. 뇌에서 전정기관의 정보를 필요로 하는 이유는 전정계가 점진 적인 진화 과정을 통하여 지구 중력에 대하여 개체의 평형을 유지하는 기능을 개발하게 되었고 그에 따라 안정된 신체의 방 향성을 제공하여 주기 때문이다. 또한 시각계가 주변 환경에서 안정된 시야를 유지할 수 있는 정보를 함께 공급하여 주기 때 문에 시각계가 차단되거나 몸체의 운동을 동반하는 움직이는 주변 환경에서는 전정계가 머리와 몸체의 움직임을 공간에서 인지하는 기능을 가지는 유일한 감각기가 된다.

간단히 요약하자면 전정계의 역할은 공간에서 머리의 움직 임과 위치에 대한 정보를 정확하고 빠르게 감지하여 중추신경 계를 통해 그에 관련된 부위가 적절한 반응을 보이도록 자극을 전달하고, 신체는 자세유지와 안정된 시야를 유지하도록 하는 데 있다.

\section{USABILITY OF VESTIBULAR FUNCTION TEST}

전정계 이상이 동반된 경우 즉각적이고 비정상적인 운동반사 가 유발되게 되고 인체는 균형감각을 잃게 되어 어지러움을 느 끼게 된다. 어지러움은 오심과 구토를 동반하는 매우 불쾌한 증상이다. 어지럼증의 발현은 시각 정보나 전정 감수기에 비 정 상적인 정보 입수가 일어나는 경우 또는 손상이 동반된 경우에 흔히 경험 할 수 있다.

인체는 균형감각이 저하되고 평형을 유지하기 어려운 상태를 느끼게 될 때 신체의 평형을 확보하기 위한 여러 가지 반사를 일으키게 되고, 특히 전정안반사(VOR)는 공간 내에 정지되어 있는 사물을 정확하게 볼 수 있도록 머리의 운동을 보상해 준 다. 그러므로 전정기관의 병적인 상태를 확인하기 위하여 시행 되는 전정기능검사는, 전정계와 시각계가 서로의 정보를 종합 하여 발현되는 안구운동을 검사하는 것이 중심을 이룬다. 전정 안반사는 전정계를 대표하는 반사작용이고 환자가 느끼는 증 상과 진찰 소견을 가장 많이 반영하기 때문에 전정계와 시각계 에 자발적 또는 인위적인 조작을 가함으로써 그 자극에 의해 유발되는 안구운동의 적정여부를 평가하여 개체의 상태가 평 형기능과 관련하여 이상적으로 병적 상태인가를 판별할 수 있 는 도구가 된다.

전정기능을 평가하는 이유는 첫째, 장애부위를 진단하기 위 해 실시한다. 중추성 어지럼증과 말초성 어지럼증의 감별진단 (localization)과, 중추성 어지러움인 경우 병변의 위치를 알아 내고 말초성 어지러움인 경우 좌 우측의 측 별 구분(lateraliza- tion)을 하거나 병변이 양측에 있는지를 검사하여 병소의 편측 성을 판단하는 데 도움을 준다.

둘째, 어지럼증이 있는 환자의 전정기능 장애 정도의 판정을 위해 실시한다. 말초성병변의 경우 건측과 비교하여 기능의 장애 정도를 평가하거나 다른 감각기와 대략적인 비교가 가능하다.

셋째, 환자의 어지럼증 치료에 대한 효과의 판정을 하는 정 보로 활용하기 위해 실시한다. 어지럼증에 대한 보상, 적응, 습 관화의 정도를 주기적으로 추적 관찰하는데 도움을 주며 약물 이나 수술적 치료 후에 치료효과를 판정하고 기록함으로써 의 사소통에 도움을 준다.

넷째, 전정기능검사는 어지럼증환자에 대한 치료과정에서 환 자의 상태를 평가하여 의료진과, 환자, 보호자사이의 의사소통 을 원활하게 하고 신뢰관계를 설정하는데 중요한 자료가 되므 로 어지러움의 평가에 필수적이다.

전정기능을 평가하기 위하여 시행되는 검사방법은 수평반고 리관의 기능평가에 편중 되는 경향을 보였으나 최근에는 영상 안진기를 활용함으로써 진단의 신뢰성이 향상되었을 뿐만 아니 라 자료의 분석과 연구가 활발히 이루어지는 원동력이 되었다.

전정기능을 평가하기 위해 영상안진검사, 냉온교대온도안진 검사, 회전검사, 체평형검사, 두위 및 두위변환검사, 전정유발근 전위검사와 주관적 수직 수평검사, 비디오두부충동검사 등의 다양한 검사법을 적용하여 안구운동의 적정여부를 평가하고 이상부위의 진단과 이상 정도, 현재 상황이 평형유지와 관련한 병적상태인지 아닌지 여부를 확인할 수 있다.

결과에 따라 중추성인지 말초성어지럼인지를 판별하고 좌우 이상부위와 손상 정도를 감별할 수 있기 때문에 임상적인 진단 과 치료를 통해 어지럼과 평형장애를 치료하는 과정이 이어진 다(Lee \& Lee, 2004). 그러나 이러한 과정을 진행하여도 지속 적인 어지럼과 불균형감이 나타나는 경우는 적극적인 재활프로 그램이 필요하다. 전정재활이 필요한 대상은 약 6 개월 이상 불편 함을 호소하는 만성적인 경우, 약물복용 등으로 증상은 회복되 었으나 기능저하가 남아있는 경우와 수술 또는 외상, 급성전정 기능장애가 초래된 경우에 전정재활이 매우 효과적인 증상 개 선효과를 줄 수 있다(Han et al., 2011).

\section{PHYSICAL THERAPY OF BALANCE DISORDER}

전정재활은 현재의 어지럼과 시야불안정상태를 완화시키고, 균형유지 능력을 증대시키며, 일상생활이 가능하도록 사회복귀 를 돕는 것이다. 여기에는 의료진과 재활전문가, 사회복지사등 전문가그룹의 포괄적인 접근을 통해 개개인의 능력에 맞게 다 양한 재활프로그램을 적절하게 개발하고 목표에 이를 수 있도 
록 교육하고 진행과정을 지원하여야 한다. 프로그램을 진행하 기 위해서는 정확하 현재 상태의 확인이 매우 중요하다.

전정재활은 적응(adaptation), 습관화(habituation), 대치 (substitution)의 큰 원칙으로 증상에 맞게 적용하지만 최근에 는 통합된 프로그램을 많이 사용하고 있다. 현재 상태로 자신 을 환경에 반복적으로 노출시켜 자극에 대한 반응이 점차적으 로 감소되도록 적응력을 높이기, 저하된 기능상태에서 평형감 을 유지하도록 강화시키기, 손상된 기관(전정계) 대신 다른 관 련 감각기관(시각계, 고유체성감각계)을 활성화 하여 대체하기 등의 전략을 바탕으로 운동치료계획을 수립할 수 있다. 난이도 가 낮은 활동에서 높은 활동으로 강도를 조절하고 활동반경을 점차 넓혀 실내활동을 외부활동으로 확장시키고, 일인활동에 서 여러 사람과 어울려 주고받기가 가능한 대인활동으로 변화 시키며 활동 시간도 점차 증가시켜서 각각의 환경에 맞게 균형 감을 조절하는 능력을 키워나가도록 한다. 이 과정은 모든 재활 치료가 그렇듯이 불안정상태가 개선되기까지 일정기간이 필요 할 뿐만 아니라 대상자의 적극적인 의지와 협조가 요구된다.

이러한 결과들이 전정 재활이 진행되는 동안 신뢰도 높은 평 가자료와 치료과정의 효율성을 판단하는 기준이 될 수 있는 표 준화된 척도가 필요하다. 대표적으로 많이 사용되는 어지럼증 설문(DHI, KDHI), 운동성 어지럼지수(MSQ), 일상생활 능력 지수(ADL) 등을 예로 들 수 있다. 객관화 하여 비교할 수 있도 록 체계화 하는 과정이 있어야 하며 재활 대상자의 상태에 대한 정보가 누락되지 않게 기록하는 것이 중요하다. 정기적으로 스 케일의 변화 정도를 확인하여야 한다. 장 단기의 활동목표를 세 우고 정기적으로 객관화된 평가도구를 사용하여 재활운동의 효과를 확인하고 계획을 수정하거나 조절하는데 있어서 융통 성을 부여한다. 이러한 척도들은 대상자의 상태를 감성적측면 (Emotion), 기능적측면(function), 신체적측면(physical) 전반에 걸쳐 이해하는데 도움을 주기 때문에 맞춤치료전략을 세우는 데 무엇보다 중요한 정보가 될 수 있다.

전정재활을 진행하는데 고려해야 할 것은 재활프로그램의 진행을 어렵게 하는 요소가 없는지 확인하는 것이다. 기능적으 로 전정기능의 보상을 저해하는 요인이 존재하기 때문이다. 노 령에 의한 활동력 저하, 중추성 질환의 동반여부, 신체적 질환 으로 인한 재활의 어려움 등이 프로그램을 진행하여도 그 효 과를 현저히 낮게 만들 수 있으며 가족과 공동체의 지지와 대 상자의 심리적인 부분도 많은 영향을 미치기 때문에 다각적인 측면에서 접근이 필요하다.

\section{DISCUSSION}

인체는 외부의 다양한 자극에 대하여 적절하게 반응함으로
기존의 항상성을 유지하는 시스템을 갖고 있다. 자극을 수용하 는 감각기관들은 매우 민감하며 인체는 여러 가지 방법으로 그 결과를 표현해 낸다. 특별히 인체의 신체 균형을 유지하는 감각 은 고유체성감각계, 시각계와 전정계의 상호작용으로 이루어지 며 사지의 움직임, 시야의 안정성 및 자율신경계의 반응으로 나 타난다.

인체의 평형감각에 이상이 발생하면 심각한 어지럼과 자세 를 바르게 유지하기 어렵게 되며 오심과 구토 등이 동반된다. 평형감각의 이상 여부를 판단하기 위해 전문적인 지식과 장비 를 이용한 평가를 진행하고 문제가 확인되면 결과에 따라 필요 한 수술 및 약물치료와 증상의 호전 정도를 관찰하기 위한 추 적관리가 재활과정을 통해 이루어진다. 어지럼의 정확한 원인 을 규명하기는 어려움이 있으나 어지럼과 불균형감은 질병의 특성에 따라, 발생 부위에 따라 일관적이고 유사한 증상을 보 이기 때문에 그 관리가 어려운 것은 아니다. 어지럼과 불균형감 은 집중력을 저하시키고, 평범한 일상생활을 어렵게 하며 사회 활동에 지장을 초래하게 되므로 정확한 진단과 치료 및 재활과 같이 효과적인 사후관리가 필요하다. 우리의 현실은 체계적인 전정재활치료를 시행하기에 사회인식과 전문적인 재활관련 시 스템의 결여로 인해 진정한 의미에서의 프로그램을 제공하기 쉽 지 않은 상황이다.

어지럼과 균형장애를 갖고 있는 환자의 남아있는 기능을 활 용하여 일상으로 복귀할 수 있도록 돕는 것 전정재활의 목적임 을 기억하고 어지럼에 대한 이해를 기초로 정확한 진단, 환자 상 태에 대한 적절한 치료계획을 수립하는 노력을 기울여야 한다.

중심 단어 : 평형·중력점·어지럼증·전정안반사·재활.

\section{REFERENCES}

Baloh, R. W. \& Halmagyi, G. M. (1996). Disorders of the Vestibular System. Oxford university press.

Han, B. I., Song, H. S., \& Kim, J. S. (2011). Vestibular Rehabilitation Therapy: Review of Indications, Mechanisms, and Key Exercises. Journal of Clinical Neurology, 7(4), 184-196.

Herdman, S. J. (2007). Vestibular Rehabilitation. FA Davis.

Lee, S. C. \& Lee, W. S. (2004). Vestibular function test. Seoul, Korea: Jingihoek.

Lee, W. S., Lee, J. G., Jung, K. C., Park, B. L., \& Han, K. C. (2005). Equilibrium and Disequilibrium. Paju, Korea: Koonja.

Peterson, B. W., Goldberg, J., Billoto, G., \& Fuller, J. H. (1985). Cervicocollic Reflex : its dynamic properties and interaction with vestibular reflexes. Journal of Neurophysiology, 54(1), 90-109.

Rhee, C. G. (2003). Dizziness. Dankook university press. 